\title{
Olanzapine, but Not Fluoxetine, Treatment Increases Survival in Activity-Based Anorexia in Mice
}

\author{
Stephanie J Klenotich', Mariel P Seiglie ${ }^{2}$, Matthew S McMurray ${ }^{3}$, Jamie D Roitman ${ }^{3}$, Daniel Le Grange², \\ Priya Dugad ${ }^{2}$ and Stephanie C Dulawa*,1,2 \\ 'Committee on Neurobiology, University of Chicago, Chicago, IL, USA; ${ }^{2}$ Department of Psychiatry and Behavioral Neuroscience, University of \\ Chicago, Chicago, IL, USA; ${ }^{3}$ Department of Psychology, University of Illinois at Chicago, Chicago, IL, USA
}

\begin{abstract}
Anorexia nervosa (AN) is an eating disorder characterized by extreme hypophagia, hyperactivity, and fear of weight gain. No approved pharmacological treatments exist for AN despite high mortality rates. The activity-based anorexia (ABA) phenomenon models aspects of AN in rodents, including progressive weight loss, reduced food intake, and hyperactivity. First, we optimized the ABA paradigm for mice. We compared mouse strains (Balb/c), A/J) for susceptibility with ABA, and evaluated the effects of different food access durations (2, 4, 6, 8 , and $10 \mathrm{~h}$ ) on ABA parameters. Balb/c) mice exhibited significantly shorter survival time (days until $25 \%$ bodyweight loss) in the ABA paradigm compared with $\mathrm{A} / \mathrm{J}$ mice. Furthermore, $6 \mathrm{~h}$ of food access reduced survival in mice housed with wheels without reducing survival in mice housed without wheels. We then evaluated the effects of chronic treatment with fluoxetine (4 weeks) or subchronic treatment with olanzapine $(O L Z)$ ( I week) on $A B A$ in $B A L B / c \mid$ mice. $O L Z(12 \mathrm{mg} / \mathrm{kg} /$ day) significantly increased survival and reduced food anticipatory activity (FAA). However, OLZ did not alter food intake or running wheel activity during ad-lib feeding (baseline) or restriction conditions, or in mice housed without wheels. Fluoxetine $(18 \mathrm{mg} / \mathrm{kg} /$ day $)$ increased food intake and reduced FAA, but did not alter survival. Here, we report for the first time that $O L Z$, but not fluoxetine, reduces ABA in mice. Our findings indicate further need for clinical investigations into the effects of $\mathrm{OLZ}$, but not selective serotonin reuptake inhibitors, on core features of $A N$.

Neuropsychopharmacology (2012) 37, 1620-1631; doi:I0.1038/npp.2012.7; published online 7 March 2012
\end{abstract}

Keywords: activity-based anorexia; anorexia nervosa; balb/c); fluoxetine; olanzapine; survival

\section{INTRODUCTION}

Anorexia nervosa (AN) is an eating disorder characterized by profound hypophagia, refusal to maintain a normal body weight, and fear of weight gain. Moreover, AN patients often exhibit hyperactivity, manifesting as extreme exercise or general restlessness (Hebebrand et al, 2003; Kron et al, 1978). AN occurs primarily in females, and has the highest mortality rate of all psychiatric disorders (Arcelus et al, 2011; Sullivan, 1995). Despite the severity of AN, no approved pharmacological treatments currently exist.

Abnormalities of the serotonin (5-hydroxytryptamine, 5-HT) neurotransmitter system have been reported in both ill and recovered AN patients. The major metabolite of 5-HT, 5-hydroxyindoleacetic acid (5-HIAA), is reduced during illness and elevated after weight restoration (Kaye et al, 1988, 1991). Furthermore, several PET imaging studies

*Correspondence: Dr SC Dulawa, Department of Psychiatry and Behavioral Neuroscience, University of Chicago, 924 E 57th Street, Room 022, MC 3077 Chicago, IL 60637, USA, Tel: + I 773702 6369, Fax: + I 773702 9062, E-mail: dulawa@uchicago.edu Received 25 July 2011; revised 21 December 2011; accepted 24 December 201। have found that patients ill or recovered from AN have increased $5-\mathrm{HT}_{1 \mathrm{~A}}$ receptor (Bailer et al, 2005, 2007a) and serotonin transporter binding (Bailer et al, 2007a), and decreased $5-\mathrm{HT}_{2 \mathrm{~A}}$ receptor binding (Audenaert et al, 2003; Frank et al, 2002). These alterations in the 5-HT system remain following weight restoration, and thus, are likely traits of AN. Genetic association studies have linked polymorphisms in the serotonin transporter and $5-\mathrm{HT}_{2 \mathrm{~A}}$, $5-\mathrm{HT}_{1 \mathrm{D}}$, and $5-\mathrm{HT}_{3}$ receptor genes with AN (Bergen et al, 2003; Brown et al, 2007; Delorme et al, 2005; Monteleone and Maj, 2008; Ozaki et al, 2003). However, genome-wide association studies to date have not identified significant associations of any genes and AN (Wang et al, 2011).

Pharmacotherapy targeting the serotonergic system has been attempted in AN patients. Treatment with selective serotonin reuptake inhibitors (SSRIs) has been unsuccessful for malnourished patients (Attia et al, 1998; Ferguson et al, 1999; Holtkamp et al, 2005). One randomized-controlled trial (RCT) found that fluoxetine treatment reduces relapse (Kaye et al, 2001) in weight-restored patients; however, the largest RCT to date (Walsh et al, 2006) found fluoxetine to be ineffective in reducing relapse in AN. Thus, the effects of fluoxetine on AN remains unclear.

The dopamine (DA) system regulates reward processing, movement, and feeding behavior, and is also altered in AN. 
Ill and recovered $\mathrm{AN}$ patients exhibit reductions in homovanillic acid, a major metabolite of DA (Kaye et al, 1999), and increased DA $D_{2}$ and $D A D_{3}$ receptor binding (Frank et al, 2005). Furthermore, polymorphisms in DA $\mathrm{D}_{2}$ are associated with AN (Bulik et al, 2007; Burden et al, 1993; Monteleone and Maj, 2008). Recent findings suggest that drugs targeting both 5 - HT and DA receptors may be effective in treating AN. Several open label studies have reported that the atypical antipsychotic olanzapine (OLZ) increases body weight, and reduces hyperactivity and anxiety about eating and body shape (Barbarich et al, 2004; Dennis et al, 2006; Leggero et al, 2010). Furthermore, two preliminary RCTs recently showed that OLZ significantly reduces obsessions about weight while increasing the rate of weight gain (Bissada et al, 2008), and reduces anorexic ruminations (Mondraty et al, 2005).

The activity-based anorexia (ABA) phenomenon provides a rodent model for aspects of $\mathrm{AN}$. In the $\mathrm{ABA}$ paradigm, rodents subjected to restricted food access and housed with running wheels develop paradoxical hyperactivity, hypophagia, and extreme weight loss resulting in death. Conversely, rodents given either restricted food access or running wheels maintain body weight (Epling and Stefan 1983; Routtenberg and Kuznesof, 1967). ABA recapitulates several aspects of $\mathrm{AN}$, including weight loss, reduced food intake, hyperactivity, increased hypothalamic-pituitaryadrenal (HPA) axis activity, and loss of estrus (Burden et al, 1993; Dixon et al, 2003; Watanabe et al, 1992). Furthermore, adolescent (Boakes et al, 1999; Pare, 1975; Woods and Routtenberg, 1971) and female rodents (Klenotich and Dulawa, in press; Paré et al, 1978) develop more severe ABA phenotypes. Recently, the effects of SSRIs and OLZ on ABA have been investigated in rats. FLX (5 mg/kg/day) (Altemus et al, 1996), fluvoxamine (50 mg/kg/day) (Yokoyama et al, 2007), and OLZ (7.5 mg/kg/day) (Hillebrand et al, 2005) were all reported to reduce $A B A$.

The present studies investigated the effects of chronic treatment with the SSRI FLX or the atypical antipsychotic OLZ on ABA in mice. We first performed a strain comparison study to identify a mouse strain with high vulnerability to ABA, because mice show strain differences in ABA susceptibility (Gelegen et al, 2007, 2008, 2010). We then optimized ABA experimental parameters for investigating drug treatment effects in mice. For example, food access duration can alter the progression of ABA (Pare et al, 1985; Watanabe et al, 1992). Next, we identified doses of OLZ (12 mg/kg/day, $24 \mathrm{mg} / \mathrm{kg} /$ day) that alter ABA behavior. Finally, we determined the effects of chronic FLX $(18 \mathrm{mg} / \mathrm{kg} /$ day) or subchronic OLZ (12 mg/kg/day) treatment on ABA behavior.

\section{MATERIALS AND METHODS}

\section{Animals}

Experimentally naive Balb/cJ and A/J female mice (Jackson Laboratories, Bar Harbor, ME) were aged 6-8 weeks at the beginning of all experimental procedures. Mice were given ad libitum access to standard chow and water, except during food restriction periods described below. Animals were euthanized, or 'dropped', from experiments when they lost $25 \%$ of their initial body weight, defined on the last day of baseline. All procedures were conducted in accord with the National Institutes of Health laboratory animal care guidelines and with the Institutional Animal Care and Use Committee approval at the University of Chicago.

\section{Drugs}

All drugs were administered in the drinking water in dark bottles. Fluoxetine hydrochloride (BIOTREND, Cologne, Germany) treatment was initiated 4 weeks before the restriction period since FLX has a therapeutic onset of 2-4 weeks in humans (Blier, 2003; Fineberg et al, 1992). FLX was dissolved in distilled water. In contrast to FLX, OLZ (Sequoia Research Products, Pangbourne, UK) has more rapid therapeutic onset (1-2 weeks) (Fulton and Goa, 1997); treatment began during the baseline period. OLZ was dissolved in a minimal quantity of glacial acetic acid, raised to volume with distilled water, and adjusted to a $\mathrm{pH}$ of 5.7-5.8. During baseline and restriction periods the same proportion of glacial acetic acid was added to FLX and vehicle control (VEH) solutions, which were also adjusted to a $\mathrm{pH}$ of 5.7-5.8. Drug concentrations were adjusted to account for changes in water intake and body weight twice weekly during baseline conditions. Drug solutions were changed daily from weekly stock solutions during food restriction conditions. Water intake values for drug-treated mice are shown in Supplementary Table 1.

\section{Experimental Conditions}

Animals were housed in a climate-controlled room maintained on a 12:12 light dark cycle (lights off at 1800 hours). Cages $(19.56 \times 34.70 \times 14.41 \mathrm{~cm})$ were equipped with wireless low-profile running wheels (Med Associates, St Albans, VT). Running wheels transmitted running data at 30-s intervals to a computer with Wheel Manager Software (Med Associates) $24 \mathrm{~h}$ a day throughout the experiment. Food was provided in a small glass jar $(65 \mathrm{~cm}$ diameter $\times 50 \mathrm{~cm}$ height).

\section{ABA Procedure}

All animals were pseudo-randomly divided in experimental groups based on their body weights. During acclimation, baseline, and food restriction periods, mice were singly housed and given 24-h access to running wheels. For some experiments, additional groups of mice were treated identically, but were not provided running wheels. Daily body weight, food intake, running wheel activity, and food anticipatory activity (FAA) were recorded during baseline and food restriction conditions. FAA refers to running wheel activity during the $4 \mathrm{~h}$ preceding food delivery (Davidson and Stephan, 1999; Holmes and Mistlberger, 2000; Honma et al, 1983; Mistlberger, 1994). Days to dropout (loss of $25 \%$ baseline body weight) provided a measure of survival. 


\section{Experiment 1: Effect of Mouse Strain on ABA}

Female Balb/cJ $(n=15)$ and A/J $(n=15)$ mice 6 weeks of age were acclimated to running wheels for 3 days before the baseline period. Following 4 days of baseline conditions, mice were given $2 \mathrm{~h}$ of food access per day beginning at 1000 hours.

\section{Experiment 2: Effect of Food Access Duration on ABA}

Eight-week-old female Balb/cJ mice $(n=72)$ were acclimated to wheel $(n=36)$ or non-wheel $(n=36)$ housing conditions for 2 days. Following 7 days of baseline conditions, mice housed with and without wheels received $2 \mathrm{~h}$ ( $n=7$ per group), $4 \mathrm{~h}$ ( $n=7$ per group), $6 \mathrm{~h}$ ( $n=8$ per group), $8 \mathrm{~h}$ ( $n=7$ per group), and $10 \mathrm{~h}$ ( $n=7$ per group) of food access during the restriction period. Food was given at 0800 hours each day. Mice were euthanized after losing $25 \%$ of baseline body weight, or following 12 days of restriction.

\section{Experiment 3: Dose-Dependent Effects of Subchronic OLZ Treatment on ABA}

Female Balb/cJ mice $(n=15)$ aged 8 weeks were acclimated to running wheels for 2 days. During baseline ( 7 days), mice received $\mathrm{VEH}(n=5)$, OLZ $12 \mathrm{mg} / \mathrm{kg} /$ day $(n=5)$, or OLZ $24 \mathrm{mg} / \mathrm{kg} /$ day $(n=5)$. During the restriction period, food was given for $6 \mathrm{~h}$ per day beginning at 0800 hours. Mice were euthanized following either $25 \%$ loss of baseline body weight or 14 days of restriction.

\section{Experiment 4: Effects of Chronic FLX and Subchronic OLZ Treatment on ABA}

Female Balb/cJ mice $(n=60) 6$ weeks of age were treated with either VEH ( $0 \mathrm{mg} / \mathrm{kg} /$ day, $n=20)$, OLZ (12 mg/kg/day, $n=20)$, or FLX $(18 \mathrm{mg} / \mathrm{kg} /$ day, $n=20)$ and housed either with or without running wheels. Following the acclimation to single housing and running wheels (3 days) and the baseline period ( 7 days), mice received $6 \mathrm{~h}$ of food access a day beginning at 0800 hours. Mice were euthanized either after $25 \%$ baseline body weight loss, or 14 days had elapsed.

\section{Statistical Analysis}

For baseline data, ANOVAs assessed the effects of group (strain, drug, food access period, or wheel) as between subjects factors, and day as a within subjects factor for each dependent variable (body weight, food intake, running wheel activity, and FAA). When significant interactions were found, post hoc comparisons were made using the Student-Newman-Keuls test for between subjects factors or post hoc ANOVAs for within subjects factors. Bonferroni adjustments were made when post hoc ANOVAs were applied.

For restriction data, the linear mixed effects model (mixed ANOVA model) was used to assess differences in body weight, food intake, running wheel activity, and FAA. Mice continually drop out of the ABA paradigm, creating data sets with missing values. Post hoc analysis resolving 'treatment $\times$ day' interactions were adjusted for multiple comparisons using the false discovery rate method. Survival analysis was performed using the Kaplan-Meier test with log-rank (Mantel-Cox) post hoc tests.

\section{RESULTS}

\section{BALB/cJ Mice Exhibit Increased Vulnerability to ABA}

During baseline, Balb/cJ mice had significantly higher body weights on day $1 \quad\left(\mathrm{~F}_{(7,28)}=3.735 ; p<0.001\right)$, and ran significantly more than $\mathrm{A} / \mathrm{J}$ mice overall $\left(\mathrm{F}_{(1,28)}=53.307\right.$; $p<0.0001)$. There were no differences in food intake between strains during baseline (Table 1). During food restriction, Balb/cJ mice weighed significantly less than $\mathrm{A} / \mathrm{J}$ mice on days 1 through $4 \quad\left(\mathrm{~F}_{(3,66)}=13.85 ; p<0.0001\right)$ (Figure 1a). Balb/cJ mice also ran significantly more than A/J mice during food restriction $\left(\mathrm{F}_{(1,66)}=7.82 ; p<0.01\right)$ (Figure 1c). A trend was found for increased FAA in Balb/cJ mice $\left(\mathrm{F}_{(1,38)}=3.01 ; p=0.09\right)$ (Figure 1d). Strain had no effect on food intake during restriction (Figure 1b). Overall, $\mathrm{A} / \mathrm{J}$ mice were more resilient to the ABA paradigm, as they survived food restriction conditions significantly longer than Balb/cJ mice $(p<0.0001)$ (Figure 1e). As Balb/cJ mice exhibited a more severe ABA phenotype, this strain was used in subsequent studies.

Table I Baseline-Dependent Measures

\begin{tabular}{|c|c|c|c|c|}
\hline Manipulation & Wheel & BW & $\mathbf{F I}$ & RWA \\
\hline $\mathrm{A} / \mathrm{J}$ & $Y$ & $17.08 \pm 0.10^{a}$ & $3.14 \pm 0.10$ & $2853.14 \pm 869.02^{a}$ \\
\hline Balb/cj & Y & $17.98 \pm 0.08$ & $3.12 \pm 0.07$ & $23219.60 \pm 1392.58$ \\
\hline $2 \mathrm{~h}$ & Y & $19.15 \pm 0.13$ & $4.37 \pm 0.09^{b}$ & $31234.89 \pm 1361.90$ \\
\hline $2 \mathrm{~h}$ & $\mathrm{~N}$ & $19.53 \pm 0.12$ & $3.75 \pm 0.07$ & - \\
\hline $4 \mathrm{~h}$ & Y & $19.14 \pm 0.11$ & $4.25 \pm 0.09^{b}$ & $34961.67 \pm 1544.30$ \\
\hline $4 \mathrm{~h}$ & $\mathrm{~N}$ & $19.09 \pm 0.12$ & $3.41 \pm 0.06$ & - \\
\hline $6 \mathrm{~h}$ & Y & $18.75 \pm 0.09^{b}$ & $3.73 \pm 0.09^{b}$ & $31573.98 \pm 1497.85$ \\
\hline $6 \mathrm{~h}$ & $N$ & $20.04 \pm 0.10$ & $3.21 \pm 0.06$ & - \\
\hline $8 \mathrm{~h}$ & Y & $18.78 \pm 0.15$ & $3.73 \pm 0.07^{b}$ & $34|81.74 \pm 167| .04$ \\
\hline $8 \mathrm{~h}$ & $\mathrm{~N}$ & $19.42 \pm 0.10$ & $3.22 \pm 0.05$ & - \\
\hline $10 \mathrm{~h}$ & Y & $18.66 \pm 0.11$ & $3.72 \pm 0.07^{b}$ & $32972.25 \pm 2000.84$ \\
\hline $10 \mathrm{~h}$ & $\mathrm{~N}$ & $19.49 \pm 0.11$ & $3.11 \pm 0.06$ & - \\
\hline $0 \mathrm{mg} / \mathrm{kg} /$ day $V E H$ & Y & $19.16 \pm 0.12$ & $3.48 \pm 0.09$ & $34572.89 \pm 2120.48$ \\
\hline $12 \mathrm{mg} / \mathrm{kg} /$ day OLZ & Y & $19.23 \pm 0.15$ & $3.27 \pm 0.15$ & $27070.11 \pm 1930.15$ \\
\hline 24 mg/kg/day OLZ & Y & $19.02 \pm 0.12$ & $3.11 \pm 0.10$ & $22398.69 \pm 1535.49$ \\
\hline $0 \mathrm{mg} / \mathrm{kg} /$ day $\vee E H$ & Y & $19.30 \pm 0.14$ & $4.44 \pm 0.11^{c}$ & $32547.43 \pm 1227.52$ \\
\hline $0 \mathrm{mg} / \mathrm{kg} /$ day $V E H$ & $\mathrm{~N}$ & $19.98 \pm 0.11$ & $3.85 \pm 0.05$ & - \\
\hline $12 \mathrm{mg} / \mathrm{kg} /$ day OLZ & Y & $19.05 \pm 0.12$ & $3.93 \pm 0.07^{c}$ & $28575.06 \pm 925.39$ \\
\hline $12 \mathrm{mg} / \mathrm{kg} /$ day OLZ & $N$ & $19.09 \pm 0.12$ & $3.60 \pm 0.07$ & - \\
\hline 18 mg/kg/day FLX & Y & $19.73 \pm 0.15$ & $4.61 \pm 0.16^{c}$ & $30070.46 \pm 1429.23$ \\
\hline $18 \mathrm{mg} / \mathrm{kg} / \mathrm{day} F \mathrm{FL}$ & $\mathrm{N}$ & $19.79 \pm 0.12$ & $3.87 \pm 0.05$ & - \\
\hline
\end{tabular}

Abbreviations: BW, daily body weight; Fl, food intake; RWA, running wheel activity during baseline.

asignificant difference from Balb/cl strain $(p<0.01)$.

bSignificant difference between wheel groups within the food access duration group $(p<0.01)$.

${ }^{c}$ Overall significant effect of wheel $(p<0.005)$.

Values are means \pm SEM. 

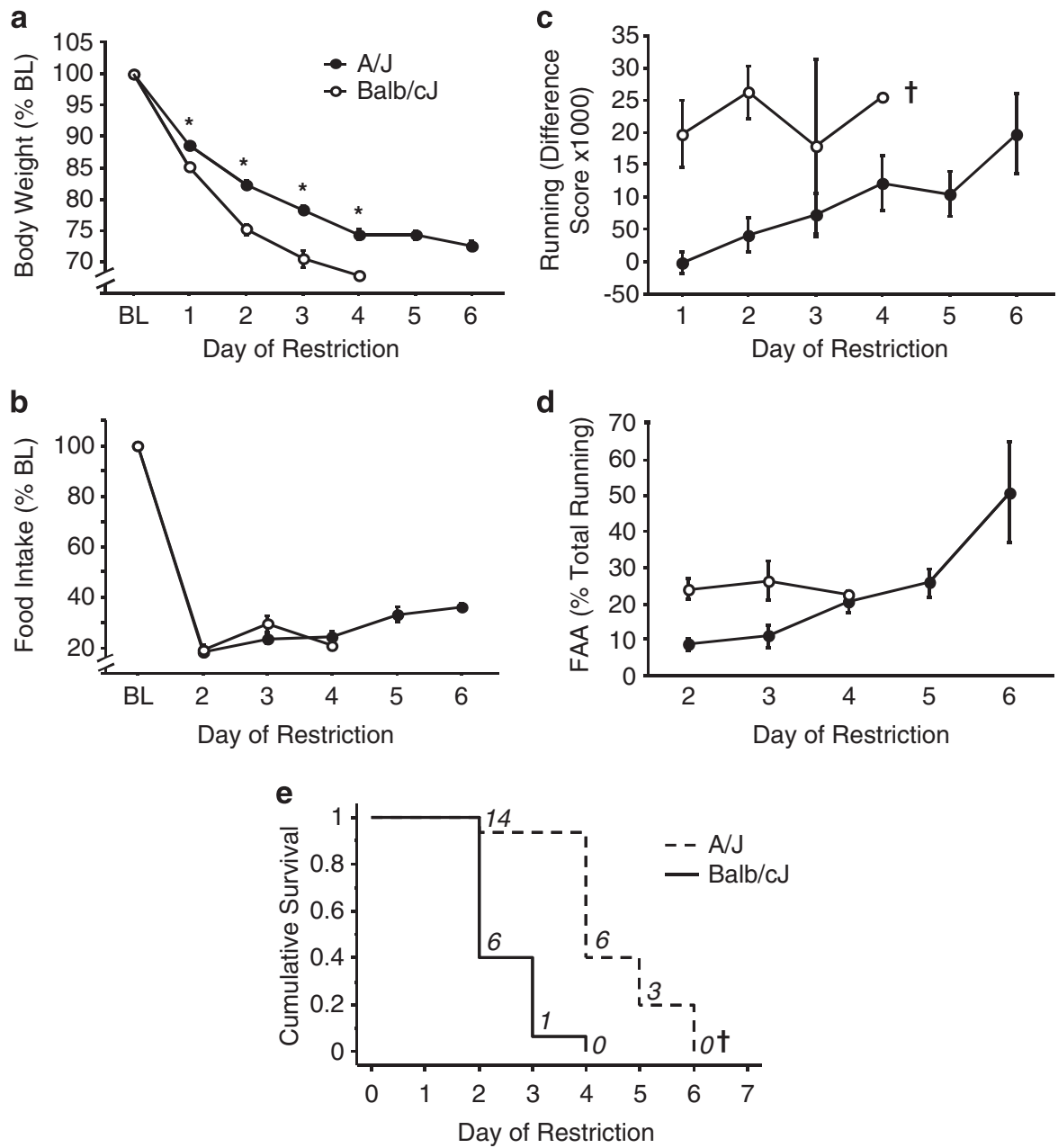

Figure I Daily body weight (a), food intake (b), running wheel activity (c), FAA (d), and survival (e) curves for A/J and Balb/cl mice during food restriction (2-h food access per day). Results expressed as mean \pm SEM. Numbers in italics represent mice remaining in food restriction. *Significant difference from Balb/cj $p<0.001$. "Significant main effect of strain, $p<0.01$.

\section{Increasing Food Access Duration Reduces ABA Behavior}

During the baseline period, body weight did not differ between animals housed with or without a wheel within the 2-, 4-, 8-, and 10-h food access duration. However, small but significant differences in body weight were found within the 6-h group $\left(\mathrm{F}_{(1,14)}=12.854 ; p<0.05\right)$ (Table 1). Mice housed with wheels had significantly higher food intake during baseline in the 2-h $\left(\mathrm{F}_{(1,12)}=25.810 ; p<0.0005\right)$, $4-\mathrm{h}$ $\left(\mathrm{F}_{(1,12)}=35.442 ; p<0.0001\right), 6-\mathrm{h}\left(\mathrm{F}_{(1,14)}=10.724 ; p<0.01\right)$, 8 -h $\left(\mathrm{F}_{(1,28)}=19.184 ; p<0.0005\right)$, and 10-h $\left(\mathrm{F}_{(1,28)}=27.001\right.$; $p<0.0001)$ groups.

During the restriction phase, survival analyses found no difference between animals housed with or without wheels given $8 \mathrm{~h}(p=0.06)$ or $10 \mathrm{~h}(p>0.05)$ of food access (Figure 2). However, mice housed without wheels survived significantly longer than those housed with wheels in the 2-h $(p<0.005)$, 4-h $(p<0.0005)$, and 6-h $(p<0.0001)$ food access groups. Six hours was the only food access duration in which all mice under wheel conditions and none of the mice under non-wheel conditions met dropout criteria. Changes in daily bodyweight, food intake, wheel running, and FAA are shown in Supplemental Results and Supplementary Figures S1, S2.

\section{Dose-Dependent Effect of Subchronic OLZ Treatment on ABA Behavior}

During the baseline period, neither $12 \mathrm{mg} / \mathrm{kg} /$ day nor $24 \mathrm{mg} / \mathrm{kg} /$ day OLZ treatment altered body weight, food intake, or running wheel activity (Table 1). During the food restriction period, mice receiving $12 \mathrm{mg} / \mathrm{kg} /$ day OLZ weighed significantly more than those receiving VEH control $\left(\mathrm{F}_{(1,32)}=6.43 ; p<0.05\right)$. Furthermore, mice receiving $24 \mathrm{mg} / \mathrm{kg} /$ day OLZ weighed significantly more than VEH-treated mice on days 3 and 4 of food restriction $\left(\mathrm{F}_{(3,32)}=4.63 ; p<0.05\right)$ (Figure 3a). Neither $12 \mathrm{mg} / \mathrm{kg} / \mathrm{day}$ nor $24 \mathrm{mg} / \mathrm{kg} /$ day OLZ altered food intake during restriction (Figure 3b). A trend for increased running wheel activity was found for mice treated with $12 \mathrm{mg} / \mathrm{kg} /$ day OLZ $\left(\mathrm{F}_{(1,32)}=3.82 ; p=0.06\right)$ compared with VEH-treated mice, while mice treated with $24 \mathrm{mg} / \mathrm{kg} /$ day ran significantly more than VEH-treated mice $\left(\mathrm{F}_{(1,22)}=14.23 ; p<0.005\right)$ (Figure 3c). Neither $12 \mathrm{mg} / \mathrm{kg} /$ day nor $24 \mathrm{mg} / \mathrm{kg} /$ day altered FAA (Figure 3d). Finally, both the $12 \mathrm{mg} / \mathrm{kg} /$ day $(p<0.05)$ 

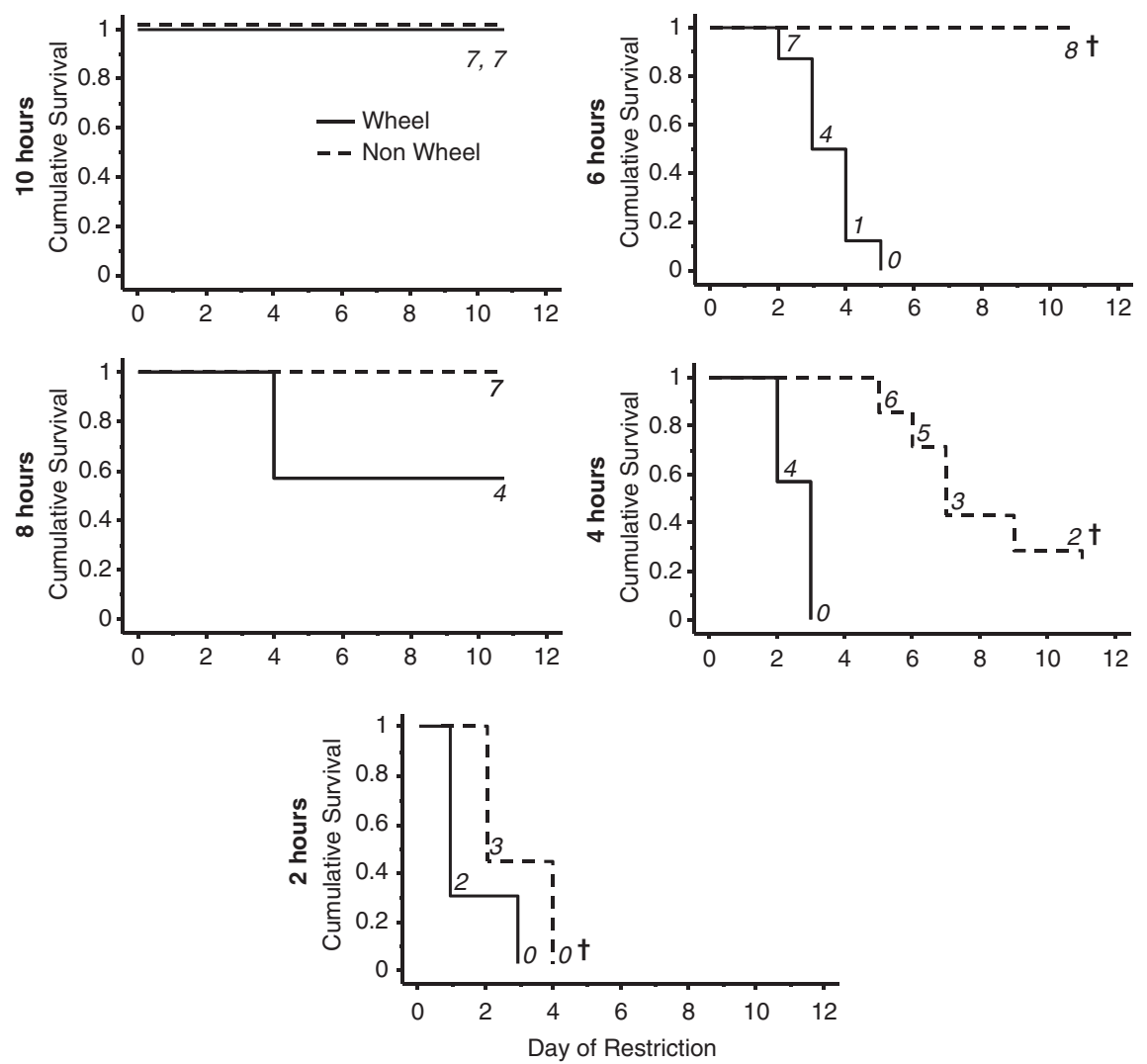

Figure 2 Survival curves for mice housed with and without wheels in each food access duration group. Results expressed as mean \pm SEM. Numbers in italics represent mice remaining in food restriction. `Significant difference from Balb/c) $p<0.005$.

and the $24 \mathrm{mg} / \mathrm{kg} /$ day doses $(p<0.05)$ of OLZ significantly increased survival compared with VEH control treatment during food restriction (Figure 3e).

\section{Subchronic OLZ, but Not Chronic FLX, Increases Survival in ABA}

Effects of chronic FLX on ABA. Chronic FLX treatment had no effect on baseline body weight, food intake, or running wheel activity in mice housed with or without wheels. Food intake was significantly increased for animals housed with wheels across treatments $\left(\mathrm{F}_{(1,36)}=9.084 ; p<0.005\right)$ (Table 1).

During the restriction period, FLX had no effect on body weight for mice housed with or without wheels (Figure $4 \mathrm{a}$, Supplementary Figure S3A). Chronic FLX treatment significantly increased food intake in mice housed with wheels $\left(\mathrm{F}_{(1,100)}=5.24 ; p<0.05\right)$ (Figure $4 \mathrm{~b}$ ), but not in mice housed without wheels (Supplementary Figure S3B). Although FLX did not alter overall daily running wheel activity (Figure 4c), FAA was decreased in FLX-treated mice on days 7,10 , 12,13 , and 14 of restriction $\left(\mathrm{F}_{(12,82)}=2.67 ; p<0.005\right)$ (Figure $4 \mathrm{~d})$. However, FLX had no effect on survival in the ABA paradigm $(p=0.16)$ (Figure $4 \mathrm{e}$ ). FLX also had no effect on survival in mice housed without wheels (Supplementary Figure S3C).

Effects of subchronic OLZ on ABA. During the baseline period, subchronic OLZ treatment decreased body weight on day $3\left(\mathrm{~F}_{(7,36)}=7.787 ; p<0.0001\right)$ regardless of wheel status. Although mice housed with wheels ate significantly more than mice without wheels across treatments $\left(\mathrm{F}_{(1,36)}=10.807 ; p<0.005\right)$, OLZ treatment significantly decreased food intake on day 1 and day 2 of baseline $\left(\mathrm{F}_{(6,36)}=4.314 ; p<0.0005\right)$. OLZ did not alter baseline running wheel activity (Table 1 ).

Subchronic OLZ treatment had no effect on body weight in mice housed with or without wheels during restriction (Figure $4 \mathrm{a}$, Supplementary Figure S3A). A trend was found for OLZ to increase food intake in mice housed with wheels $\left(\mathrm{F}_{(1,114)}=3.55 ; p=0.06\right)$ (Figure $\left.4 \mathrm{~b}\right)$, and OLZ had no effect on food intake in mice housed without wheels (Supplementary Figure S3B). Treatment with OLZ did not alter overall daily running wheel activity (Figure 4c). However, OLZ treatment significantly decreased FAA $\left(\mathrm{F}_{(1,96)}=6.14\right.$; $p<0.05$ ) (Figure $4 \mathrm{~d}$ ). Finally, OLZ treatment significantly increased survival in mice housed with wheels $(p<0.05)$ (Figure $4 \mathrm{e}$ ), and a trend for OLZ to increase survival in mice housed without wheels was found $(p=0.06)$ (Supplementary Figure S3C).

\section{DISCUSSION}

Here, we report for the first time that subchronic treatment with OLZ, but not chronic FLX, increases survival in the ABA paradigm in mice. First, we found that BALB/cJ mice exhibit shorter survival durations than $\mathrm{A} / \mathrm{J}$ mice in the $\mathrm{ABA}$ 


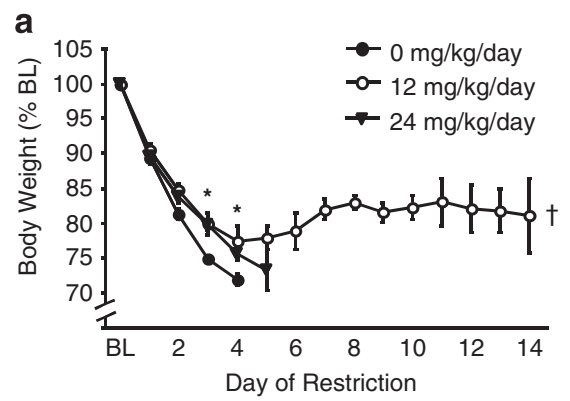

C
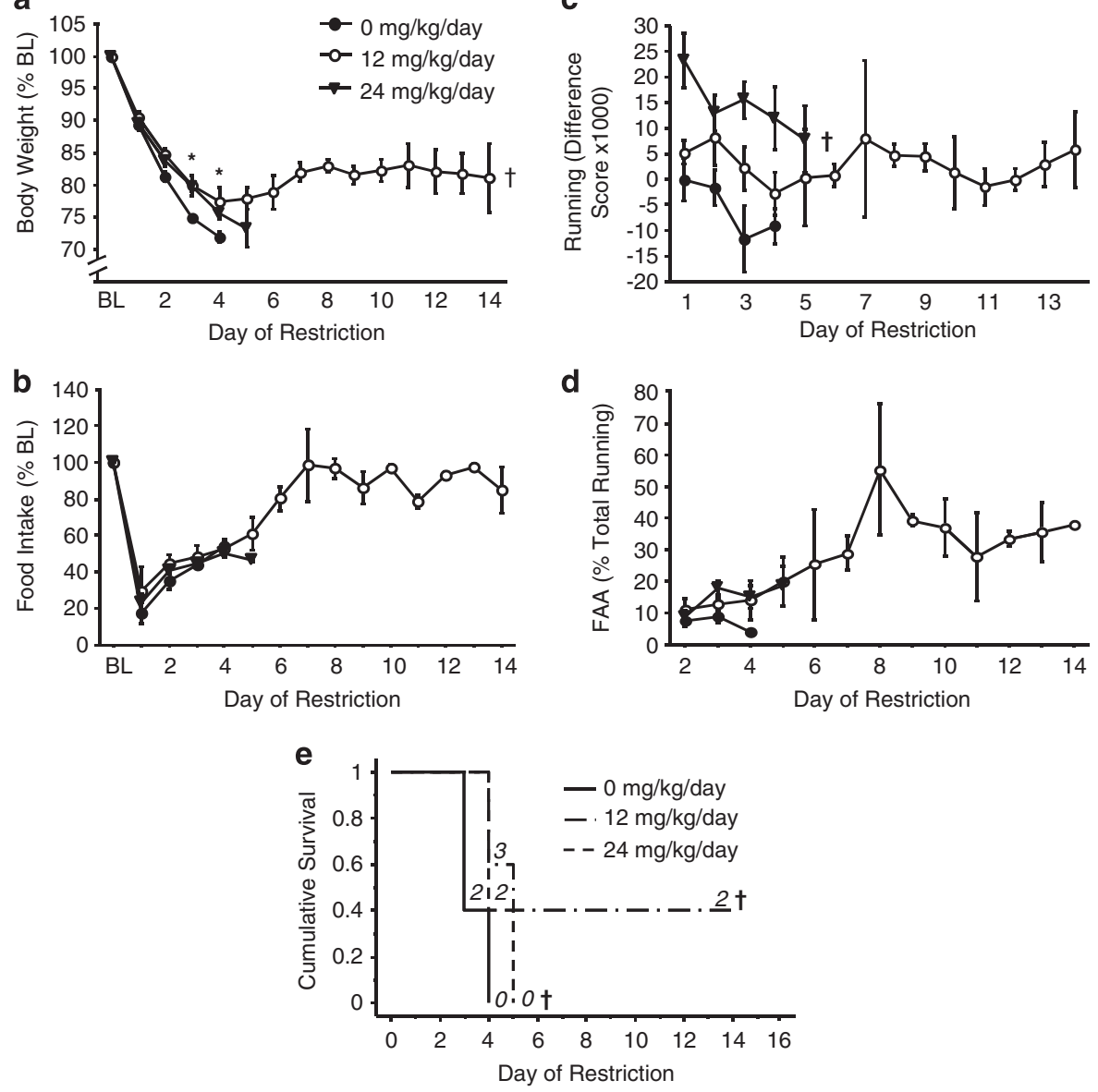

Figure 3 Daily body weight (a), food intake (b), running wheel activity (c), FAA (d), and survival (e) curves for mice treated with vehicle, 12 mg/kg/day, or $24 \mathrm{mg} / \mathrm{kg} /$ day OLZ during food restriction ( $6 \mathrm{~h}$ of food access per day). Results expressed as mean $\pm \mathrm{SEM}$. Numbers in italics represent mice remaining in food restriction. ${ }^{*} p<0.05$ vs vehicle. ${ }^{\dagger}$ Significant main effect of treatment vs vehicle, $p<0.05$.

paradigm; thus, BALB/cJ mice may provide a suitable mouse strain for modeling aspects of AN. Next, we determined the optimal food access duration for evaluating drug effects on $A B A$ using mice. We found that a 6-h food access duration induced a moderate $A B A$ phenotype, potentially allowing detection of either drug-induced increases or decreases in ABA. Finally, using these experimental conditions, we found that subchronic OLZ, but not chronic FLX, treatment increased survival in the $\mathrm{ABA}$ paradigm in $\mathrm{BALB} / \mathrm{cJ}$ mice. Although FLX-treated mice showed increases in food intake and reductions in FAA, survival in ABA was not significantly extended compared with VEH-treated mice. Conversely, OLZtreated mice exhibited significant increases in survival and reduced FAA. Our data support preliminary clinical findings on the efficacy of OLZ in AN (Bissada et al, 2008; Mondraty et al, 2005), and further validate the ABA mouse model as a tool for identifying potential treatments for AN.

The vast majority of $\mathrm{ABA}$ studies have been performed using rats. However, recent advances in molecular genetics have established mice as the foremost mammalian model for basic studies of psychiatric disorders. We therefore identified an appropriate mouse strain with which to perform ABA studies. Mouse strain differences in susceptibility to ABA have been reported previously, with the $\mathrm{A} / \mathrm{J}$ and $\mathrm{DBA} / 2 \mathrm{~J}$ strains showing increased susceptibility to developing the ABA phenotype compared with C57BL/6J mice (Gelegen et al, 2007, 2008, 2010). In fact, C57BL/6J mice do not develop $\mathrm{ABA}$, but instead show reductions in wheel running during food restriction. Our results show that $\mathrm{Balb} / \mathrm{cJ}$ mice exhibit significant decreases in body weight (Figure 1a), increases in running wheel activity (Figure 1c), and reduced survival compared with $\mathrm{A} / \mathrm{J}$ mice (Figure 1e). Interestingly, Balb/cJ mice have increased DA and DA metabolites in nucleus accumbens and prefrontal cortex, as well as decreased levels of 5-HT and 5-HIAA in comparison with $\mathrm{A} / \mathrm{J}$ mice. Balb/cJ mice also show increased DA $\mathrm{D}_{2}$ binding in nucleus accumbens in comparison with $\mathrm{A} / \mathrm{J}$ mice (Couppis et al, 2008). These data are similar to findings in ill and recovered AN patients, whom exhibit increased D2 binding potentials (Frank et al, 2005), as well as decreases in 5-HIAA (Kaye et al, 1988; Kaye et al, 1991). These differences in 5-HT and DA neurochemistry may have a role in the significantly higher susceptibility of Balb/ cJ mice for developing a severe ABA phenotype. Taken together, our findings indicate that $\mathrm{Balb} / \mathrm{cJ}$ mice exhibit high susceptibility to developing $\mathrm{ABA}$, and exhibit a neurochemical profile that supports use of this strain as an AN-like mouse. Therefore, the Balb/cJ mouse is an 
a

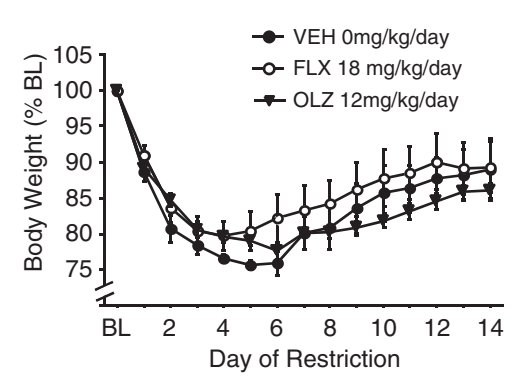

b

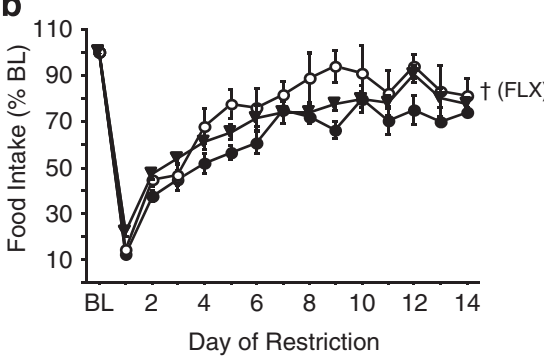

C

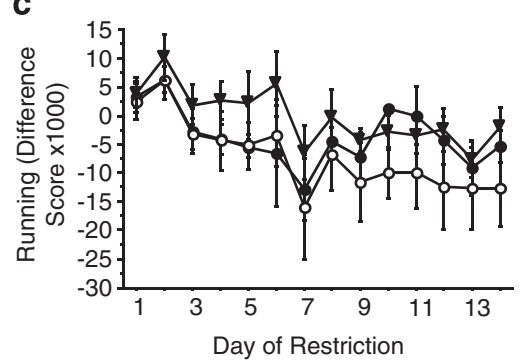

d

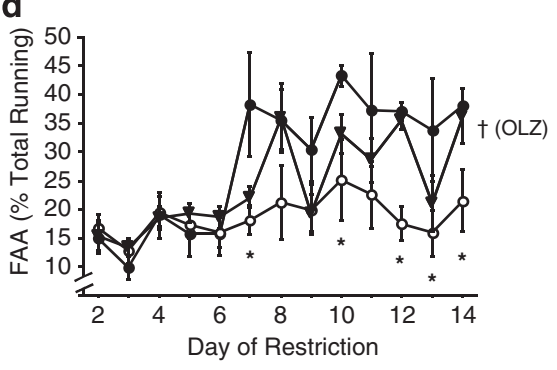

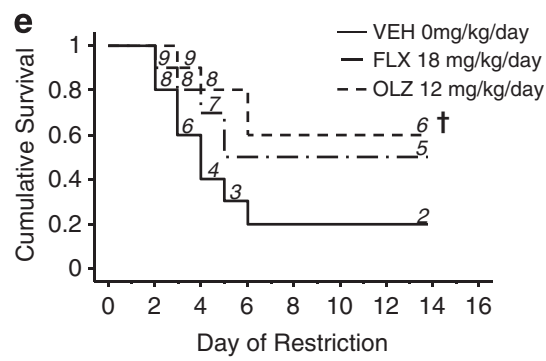

Figure 4 Daily body weight (a), food intake (b), running wheel activity (c), FAA (d), and survival (e) curves for mice treated with vehicle, $18 \mathrm{mg} / \mathrm{kg} /$ day FLX, or $12 \mathrm{mg} / \mathrm{kg} / \mathrm{day} \mathrm{OLZ}$ and housed with wheels during food restriction (6h of food access per day). Results expressed as mean $\pm \mathrm{SEM}$. $* p<0.05$ vs vehicle. Numbers in italics represent mice remaining in food restriction. 'Significant main effect of treatment vs vehicle, $p<0.05$.

appropriate strain for modeling AN-like behavior using the ABA paradigm.

We optimized the ABA paradigm for use with Balb/cJ mice. Food access duration can alter the progression of $\mathrm{ABA}$, with longer food access periods reducing the phenotype (Pare et al, 1985; Watanabe et al, 1992). Furthermore, food access durations employed in rat ABA studies (2-4h) (Pare et al, 1985; Watanabe et al, 1992) induced rapid dropout in mice housed without wheels (Figure 2), which should be able to adapt to daily food restriction and maintain body weight according to the definition of ABA (Routtenberg and Kuznesof, 1967). We sought to identify a food access duration that would extend the length of time mice survive during food restriction, allowing for the detection of decreases and increases in survival in response to various treatments. Our results indicate that $6 \mathrm{~h}$ of daily food access induces a length of survival (2-5 days) (Figure 2) that avoids both floor and ceiling effects. Mice given $6 \mathrm{~h}$ of food access showed significant reductions in body weight (see Supplementary Results, Supplementary Figure S1A), and food intake (see Supplementary Results, Supplementary Figure S1B) compared with mice without wheels. In addition, the 6-h food access condition induced dropout of all mice with wheels, whereas all mice without wheels maintained at least $75 \%$ of baseline body weight. Thus, this food access duration permits the assessment of treatment effects during food restriction conditions alone. In addition, the 8- and $10-\mathrm{h}$ food access duration times induced milder ABA phenotypes, and could be used to evaluate the effects of long-term treatments, or long-term ABA, on the brain.

Varying the food access period provided the most practical means for adjusting ABA severity. However, many other variables have been shown to affect $A B A$ severity. For example, the adaptation theory of $\mathrm{ABA}$ is based on findings that food access during the light cycle and pre-exposure to running wheels increases the ABA phenotype (Dwyer and Boakes, 1997; Ratnovsky and Neuman, 2011). Thus, adaptation to a feeding schedule that is more similar to species-typical behaviors reduces $\mathrm{ABA}$ behavior. We found that acclimation and baseline exposure to running wheels before restriction, coupled with 6 - $\mathrm{h}$ food access during restriction, produced a moderate ABA phenotype in Balb/cJ mice, which serves as a tool for investigating the effects of drug treatment on ABA. In addition to varying food access duration, our design also varies circadian feeding patterns between groups, and the effects of these two factors on ABA cannot be dissociated.

In an initial dose-finding study, we found that both 12 and $24 \mathrm{mg} / \mathrm{kg} /$ day of OLZ significantly increased survival in ABA. A previous report suggests that, OLZ reduces ABA in rats (Hillebrand et al, 2005), although the dose of OLZ used 
caused robust reductions in running wheel activity in rats fed ad libitum and food restricted rats (1-h daily food access). These findings suggest that the dose of OLZ used induced sedation. We therefore aimed to identify a nonsedative dose that would significantly reduce ABA behavior. Both the 12 and $24 \mathrm{mg} / \mathrm{kg} /$ day doses of OLZ significantly increased body weight during food restriction (Figure 3a), and increased survival in the ABA paradigm (Figure $3 \mathrm{e}$ ). Importantly, OLZ did not significantly decrease running wheel activity or increase food intake during baseline (Table 1). Although not significant, mice treated with the highest dose (24 mg/kg/day) did show about a $35 \%$ decreases in running wheel activity during baseline, illustrating that this high dose approached a sedative effect. Although only subchronic OLZ treatment ( 1 week) is sufficient to increase survival in ABA (Figures $3 \mathrm{e}$ and $4 \mathrm{e}$ ) without significant sedation or hyperphagia, an intermediate, chronic dose of OLZ (4 weeks; $16 \mathrm{mg} / \mathrm{kg} /$ day) also produces significant increases in survival (Supplementary Figure S6A) without significant increases in pre-treatment or baseline body weight (Supplementary Figure S6B) or sedation (Supplementary Figure S6D) (see Supplementary Results and Methods). In fact, chronic OLZ (16 mg/kg/day) treatment produced significant hypophagia in mice housed with wheels during baseline (Supplementary Figure S6C) (see Supplementary Results). These data indicate that chronic OLZ treatment does not induce significant increases in body weight, metabolism, or general activity levels in $\mathrm{Balb} / \mathrm{cJ}$ mice. Overall, these results indicate that subchronic (1 week) and chronic (4 weeks) OLZ treatment increases survival in ABA without inducing sedation or hyperphagia.

Our results indicate that subchronic OLZ, but not chronic FLX, treatment increases murine survival in the ABA paradigm (Figure 4e). Although both treatments appeared to increase survival under the experimental conditions employed, this effect only achieved significance in OLZtreated mice. Under food restriction conditions, neither treatment significantly altered body weight (Figure 4a, Supplementary Figure S3A). Although 12 and $24 \mathrm{mg} / \mathrm{kg} / \mathrm{day}$ of OLZ induced small but significant increases in body weight during food restriction in the dose-response study (Figure 3a), $12 \mathrm{mg} / \mathrm{kg} /$ day OLZ only induced small, nonsignificant increases in body weight during the first 6 days of food restriction in the drug comparison study (Figure 4a). Both OLZ and FLX significantly reduced FAA (Figure $4 \mathrm{~d}$ ), which contributes substantially to progressive weight loss in the ABA paradigm (Beneke et al, 1995; Dwyer and Boakes, 1997). During restriction, OLZ only produced a trend for increased food intake, while FLX significantly increased food intake during restriction (Figure $4 \mathrm{~b}$ ). However, increases in food intake did not result in significant increases in body weight or survival for FLX-treated mice. Although both OLZ and FLX reduced aspects of ABA behavior, only OLZ produced significant increases in survival (Figure 4e).

Subchronic OLZ treatment $(12 \mathrm{mg} / \mathrm{kg} /$ day $)$ and chronic OLZ treatment $(8 \mathrm{mg} / \mathrm{kg} /$ day, $16 \mathrm{mg} / \mathrm{kg} /$ day $)$ produced OLZ plasma levels (Supplementary Figure S7, S8) that are above the threshold, which predicts a therapeutic response in patients with schizophrenia (Perry et al, 2001). Only two studies, with few patients $(n=14, n=13)$ have measured OLZ plasma level in AN (Powers et al, 2002; Theisen et al,
2006), and more work needs to be done to evaluate the OLZ serum level required for therapeutic response in AN. Although the OLZ plasma levels reported here are higher than levels seen in patients with $\mathrm{AN}$, it is unclear whether these differences are due to species differences or how the ABA phenotype affect OLZ metabolism as animals approach $75 \%$ of baseline body weight. We additionally found that under conditions of 3-h daily food access, subchronic OLZ treatment $(30 \mathrm{mg} / \mathrm{kg} /$ day) significantly increased survival, whereas chronic FLX treatment $(25 \mathrm{mg} / \mathrm{kg} /$ day $)$ was ineffective (Supplementary Figure S4). Furthermore, we also found that subchronic OLZ treatment $(25 \mathrm{mg} / \mathrm{kg} /$ day, $60 \mathrm{mg} / \mathrm{kg} /$ day) increased the survival of female adolescent (4-6 weeks) $\mathrm{BALB} / \mathrm{cJ}$ mice in the ABA paradigm (Supplementary Figure S5). Our data suggest that OLZ treatment at doses ranging from approximately $12-25 \mathrm{mg} / \mathrm{kg} / \mathrm{day}$ in Balb/cJ mice given $6 \mathrm{~h}$ of food access per day significantly increase survival in ABA. These findings suggest that OLZ treatment may reduce $A N$ symptomology in patients.

SSRI treatment has previously been reported to reduce ABA in rats (Altemus et al, 1996; Yokoyama et al, 2007). The discrepancy between findings in rats and our present findings in mice may result from species differences, or differences in methodology. For example, we performed studies using $\mathrm{BALB} / \mathrm{cJ}$, a mouse strain that exhibits a robust ABA phenotype. However, the rat studies reporting effects of SSRI treatment on ABA employed commonly used rat strains, which have not been evaluated phenotypically for ABA severity. Methodological differences include the sex of rodents used and treatment duration. For example, Yokoyama et al (2007) treated male rats with a very high dose SSRI ( $50 \mathrm{mg} / \mathrm{kg} /$ day fluvoxamine) for only 7 days during restriction. Our negative findings with FLX are unlikely to have resulted from using a non-therapeutic dose because in BALB/cJ mice, as $18 \mathrm{mg} / \mathrm{kg} /$ day FLX has been shown to produce plasma FLX levels that fall in the middle of the range observed in depressed patients taking therapeutic doses (Dulawa et al, 2004). Mice receiving $18 \mathrm{mg} / \mathrm{mg} /$ day FLX in the present studies had somewhat higher plasma FLX levels than previously reported using this dose (Supplementary Figure S7) (Dulawa et al, 2004). The significant decreases in body temperature that develops during ABA could have reduced systemic clearance of FLX leading to higher plasma levels (Tortorici et al, 2007), since samples were collected as mice reached dropout criteria. Current reports conflict regarding the influence of serotonergic tone on ABA. For example, both decreasing (Atchley and Eckel, 2006), and increasing (Altemus et al, 1996) serotonergic tone have suggested to ameliorate ABA. Our results suggest that chronic FLX treatment with doses producing similar plasma levels in patients do not reduce ABA in mice.

The mechanisms by which chronic OLZ treatment increases survival in the ABA paradigm have not been identified. OLZ might increase survival in ABA by decreasing HPA axis reactivity or altering metabolism. HPA axis activity is increased during $\mathrm{ABA}$ as indicated by increased corticosterone levels (Burden et al, 1993), and corticosterone is required for the development of hyperactivity in ABA (Duclos et al, 2009). Chronic treatment with atypical antipsychotics reduces markers of HPA axis activity in patients with psychosis (Zhang et al, 2005). Thus, OLZ may 
reduce ABA by reducing HPA axis activity. Chronic OLZ treatment has also been associated with increases in body weight and metabolic syndrome (Pramyothin and Khaodhiar, 2010) in clinical populations with psychosis, suggesting alterations in metabolism (Allison et al, 1999; Newcomer, 2007). However, any OLZ-induced metabolic changes in our study are unlikely, because 12 and $24 \mathrm{mg} / \mathrm{kg} /$ day OLZ did not increase baseline body weight or food intake (Table 1).

OLZ is an antagonist at multiple neurotransmitter receptors, including $\mathrm{DA} \mathrm{D}_{1}, \mathrm{D}_{2}, \mathrm{D}_{4}, 5-\mathrm{HT}_{2 \mathrm{~A}}, 5-\mathrm{HT}_{2 \mathrm{C}}, 5-$ $\mathrm{HT}_{3}, \alpha 1$-adrenergic, histamine $\mathrm{H}_{1}$, and several muscarinic receptors (Bymaster et al, 1996). OLZ may increase survival in the ABA paradigm by blocking one or more 5-HT and/or DA receptors. Recently, Verhagen et al (2009) found that the nonselective DA antagonist cis-flupenthixol increased body weight, food intake, and body temperature during $\mathrm{ABA}$, but also reduced general locomotor activity in a sedative manner. Patients with AN likely have disruptions in 5-HT and DA signaling, because levels of DA (Kaye et al, 1999) and 5-HT (Kaye et al, 1988, 1991) metabolites are altered in ill and recovered AN patients. Furthermore, AN patients also show altered expression of specific 5-HT and DA receptors and transporters. Binding potentials for the 5$\mathrm{HT}_{1 \mathrm{~A}}$ receptor and serotonin transporter are increased (Bailer et al, 2005, 2007a, 2007b) and binding potentials for the $5-\mathrm{HT}_{2 \mathrm{~A}}$ receptor are decreased (Audenaert et al, 2003; Frank et al, 2002) in ill and recovered AN patients. Increases in $\mathrm{DA} \mathrm{D}_{2} / \mathrm{D}_{3}$ receptor binding in the ventral striatum are also seen following recovery (Frank et al, 2005). Future work should examine the receptor subtypes at which OLZ acts to reduce $A B A$.

Patients with AN find little rewarding in life beyond their drive for thinness (APA, 2000; Davis and Woodside, 2002), and abnormalities in dopaminergic signaling in AN may alter reward processing. Indeed, AN patients are more sensitive to reward and punishment (Harrison et al, 2010; Jappe et al, 2011). However, AN patients do not show the differential activation in the anterior ventral striatum distinguishing wins and losses following a reward task that control subjects exhibit (Wagner et al, 2008). Thus, AN patients may not differentiate positive and negative feedback normally. They also do not find palatable foods as rewarding (Fernstrom et al, 1994; Santel et al, 2006) have reduced novelty seeking (Harrison et al, 2010), and exhibit altered responses to taste stimuli in insular and striatal regions (Wagner et al, 2008). The suppression theory of ABA suggests that reward processes may also be altered in ABA because rodents lever press more for access to a running wheel when food deprived, and find food less salient as activity levels increase (Pierce et al, 1986).

The effects of OLZ on reward processes may contribute to its ability to reduce ABA. OLZ has variable effects on reward anticipation in the ventral striatum (Abler et al, 2007; Juckel et al, 2006; Schlagenhauf et al, 2008), and has been suggested to reduce substance abuse (Petrakis et al, 2006; Sayers et al, 2005; Smelson et al, 2006). OLZ may alter the reward saliency of wheel running, demonstrated by reductions in FAA (Figure 4d). Furthermore, OLZ has been shown to improve cognitive functioning in patients with schizophrenia (McGurk et al, 2004; Meltzer and McGurk, 1999). It is unclear whether OLZ improves cognitive function in mice. Several studies provide evidence for improvements in learning and memory (Hou et al, 2006; Mutlu et al, 2011; Wolff and Leander, 2003), while others show no effect (Rosengarten and Quartermain, 2002) or deficits (Arnt and Skarsfeldt, 1998; Mutlu et al, 2011; Skarsfeldt, 1996; Terry et al, 2002). This discrepancy may be due to differences in methodology, including duration of treatment, learning tasks, and species used. Although it is unclear whether OLZ may enhance learning in ABA, OLZtreated mice housed with wheels exhibited increased adaptation to the food restriction paradigm, as illustrated by a trend for increases food intake in comparison with vehicle-treated mice (Figure 4b). Overall, both FLX and OLZ treatment reduced FAA and increased food intake in $A B A$ in comparison with vehicle-treated mice, possibly through alterations in the reward saliency of the wheel and/or improved adaption to the food restriction paradigm via enhanced cognitive function. Nevertheless, these improvements in $A B A$ behavior only produced significant increases in survival in OLZ-treated mice. The therapeutic mechanism by which OLZ increases survival needs further investigation.

In summary, chronic OLZ treatment reduces FAA and increases survival in the ABA paradigm in mice, without inducing sedation or hyperphagia. Furthermore, chronic FLX treatment was ineffective in increasing survival in ABA. Given the high mortality rate in AN (Arcelus et al, 2011; Sullivan, 1995), approved pharmacological treatments for the disorder are sorely needed. Our findings strongly suggest that OLZ, but not FLX, may provide treatment for AN. Future work will investigate the mechanisms by which OLZ reduces $A B A$.

\section{ACKNOWLEDGEMENTS}

This work was supported by T32GM07839 (SJK) and R01MH079424 (SCD). JDR is supported by DA 027127. DLG is supported by the NIMH (R01 MH079979). He also receives royalties from Guilford Press, and honoraria from the Training Institute for Child and Adolescent Eating Disorders, LLC.

\section{DISCLOSURE}

The authors declare no conflict of interest.

\section{REFERENCES}

Abler B, Erk S, Walter H (2007). Human reward system activation is modulated by a single dose of olanzapine in healthy subjects in an event-related, double-blind, placebo-controlled fMRI study. Psychopharmacology (Berl) 191: 823-833.

Allison DB, Mentore JL, Heo M, Chandler LP, Cappelleri JC, Infante MC et al (1999). Antipsychotic-induced weight gain: a comprehensive research synthesis. Am J Psychiatry 156: 1686-1696.

Altemus M, Glowa JR, Galliven E, Leong YM, Murphy DL (1996). Effects of serotonergic agents on food-restriction-induced hyperactivity. Pharmacol Biochem Behav 53: 123-131.

APA Diagnostic and Statistical Manual of Mental Disorders DSM$I V-T R, 4$ th edn. American Psychiatric Association: Arlington, VA; (2000). 
Arcelus J, Mitchell AJ, Wales J, Nielsen S (2011). Mortality rates in patients with anorexia nervosa and other eating disorders: a meta-analysis of 36 studies. Arch Gen Psychiatry 68: 724-731.

Arnt J, Skarsfeldt T (1998). Do novel antipsychotics have similar pharmacological characteristics? A review of the evidence. Neuropsychopharmacology 18: 63-101.

Atchley DP, Eckel LA (2006). Treatment with 8-OH-DPAT attenuates the weight loss associated with activity-based anorexia in female rats. Pharmacol Biochem Behav 83: 547-553.

Attia E, Haiman C, Walsh BT, Flater SR (1998). Does fluoxetine augment the inpatient treatment of anorexia nervosa? Am J Psychiatry 155: 548-551.

Audenaert K, Van Laere K, Dumont F, Vervaet M, Goethals I, Slegers G et al (2003). Decreased 5-HT2a receptor binding in patients with anorexia nervosa. J Nucl Med 44: 163-169.

Bailer UF, Frank GK, Henry SE, Price JC, Meltzer CC, Mathis CA et al (2007a). Exaggerated 5-HT1A but normal 5-HT2A receptor activity in individuals ill with anorexia nervosa. Biol Psychiatry 61: 1090-1099.

Bailer UF, Frank GK, Henry SE, Price JC, Meltzer CC, Becker C et al (2007b). Serotonin transporter binding after recovery from eating disorders. Psychopharmacology (Berl) 195: 315-324.

Bailer UF, Frank GK, Henry SE, Price JC, Meltzer CC, Weissfeld L et al (2005). Altered brain serotonin 5-HT1A receptor binding after recovery from anorexia nervosa measured by positron emission tomography and [carbonyl $\left.{ }^{11} \mathrm{C}\right] \mathrm{WAY}-100635$. Arch Gen Psychiatry 62: 1032-1041.

Barbarich NC, McConaha CW, Gaskill J, La Via M, Frank GK, Achenbach S et al (2004). An open trial of olanzapine in anorexia nervosa. J Clin Psychiatry 65: 1480-1482.

Beneke WM, Schulte SE, vander Tuig JG (1995). An analysis of excessive running in the development of activity anorexia. Physiol Behav 58: 451-457.

Bergen AW, van den Bree MB, Yeager M, Welch R, Ganjei JK, Haque $\mathrm{K}$ et al (2003). Candidate genes for anorexia nervosa in the 1p33-36 linkage region: serotonin 1D and delta opioid receptor loci exhibit significant association to anorexia nervosa. Mol Psychiatry 8: 397-406.

Bissada H, Tasca GA, Barber AM, Bradwejn J (2008). Olanzapine in the treatment of low body weight and obsessive thinking in women with anorexia nervosa: a randomized, double-blind, placebo-controlled trial. Am J Psychiatry 165: 1281-1288.

Blier P (2003). The pharmacology of putative early-onset antidepressant strategies. Eur Neuropsychopharmacol 13: 57-66.

Boakes RA, Mills KJ, Single JP (1999). Sex differences in the relationship between activity and weight loss in the rat. Behav Neurosci 113: 1080-1089.

Brown KM, Bujac SR, Mann ET, Campbell DA, Stubbins MJ, Blundell JE (2007). Further evidence of association of OPRD1 \& HTR1D polymorphisms with susceptibility to anorexia nervosa. Biol Psychiatry 61: 367-373.

Bulik CM, Slof-Op't Landt MC, van Furth EF, Sullivan PF (2007). The genetics of anorexia nervosa. Annu Rev Nutr 27: 263-275.

Burden VR, White BD, Dean RG, Martin RJ (1993). Activity of the hypothalamic-pituitary-adrenal axis is elevated in rats with activity-based anorexia. J Nutr 123: 1217-1225.

Bymaster FP, Calligaro DO, Falcone JF, Marsh RD, Moore NA, Tye NC et al (1996). Radioreceptor binding profile of the atypical antipsychotic olanzapine. Neuropsychopharmacology 14: 87-96.

Couppis MH, Kennedy CH, Stanwood GD (2008). Differences in aggressive behavior and in the mesocorticolimbic DA system between A/J and BALB/cJ mice. Synapse 62: 715-724.

Davidson AJ, Stephan FK (1999). Feeding-entrained circadian rhythms in hypophysectomized rats with suprachiasmatic nucleus lesions. Am J Physiol 277: R1376-R1384.

Davis C, Woodside DB (2002). Sensitivity to the rewarding effects of food and exercise in the eating disorders. Compr Psychiatry 43: $189-194$.
Delorme R, Betancur C, Wagner M, Krebs MO, Gorwood P, Pearl P et al (2005). Support for the association between the rare functional variant $\mathrm{I} 425 \mathrm{~V}$ of the serotonin transporter gene and susceptibility to obsessive compulsive disorder. Mol Psychiatry 10: 1059-1061.

Dennis K, Le Grange D, Bremer J (2006). Olanzapine use in adolescent anorexia nervosa. Eat Weight Disord 11: e53-e56.

Dixon DP, Ackert AM, Eckel LA (2003). Development of, and recovery from, activity-based anorexia in female rats. Physiol Behav 80: 273-279.

Duclos M, Gatti C, Bessiere B, Mormede P (2009). Tonic and phasic effects of corticosterone on food restriction-induced hyperactivity in rats. Psychoneuroendocrinology 34: 436-445.

Dulawa SC, Holick KA, Gundersen B, Hen R (2004). Effects of chronic fluoxetine in animal models of anxiety and depression. Neuropsychopharmacology 29: 1321-1330.

Dwyer DM, Boakes RA (1997). Activity-based anorexia in rats as failure to adapt to a feeding schedule. Behav Neurosci 111: 195-205.

Epling WF PW, Stefan L (1983). A theory of activity-based anorexia. Int J Eat Disord 3: 27-46.

Ferguson CP, La Via MC, Crossan PJ, Kaye WH (1999). Are serotonin selective reuptake inhibitors effective in underweight anorexia nervosa? Int J Eat Disord 25: 11-17.

Fernstrom MH, Weltzin TE, Neuberger S, Srinivasagam N, Kaye WH (1994). Twenty-four-hour food intake in patients with anorexia nervosa and in healthy control subjects. Biol Psychiatry 36: 696-702.

Fineberg NA, Bullock T, Montgomery DB, Montgomery SA (1992). Serotonin reuptake inhibitors are the treatment of choice in obsessive compulsive disorder. Int Clin Psychopharmacol 7(Suppl 1): 43-47.

Frank GK, Bailer UF, Henry SE, Drevets W, Meltzer CC, Price JC et al (2005). Increased dopamine D2/D3 receptor binding after recovery from anorexia nervosa measured by positron emission tomography and [11c]raclopride. Biol Psychiatry 58: 908-912.

Frank GK, Kaye WH, Meltzer CC, Price JC, Greer P, McConaha C et al (2002). Reduced 5-HT2A receptor binding after recovery from anorexia nervosa. Biol Psychiatry 52: 896-906.

Fulton B, Goa KL (1997). Olanzapine. A review of its pharmacological properties and therapeutic efficacy in the management of schizophrenia and related psychoses. Drugs 53: 281-298.

Gelegen C, Collier DA, Campbell IC, Oppelaar H, van den Heuvel J, Adan RA et al (2007). Difference in susceptibility to activitybased anorexia in two inbred strains of mice. Eur Neuropsychopharmacol 17: 199-205.

Gelegen C, Pjetri E, Campbell IC, Collier DA, Oppelaar H, Kas MJ (2010). Chromosomal mapping of excessive physical activity in mice in response to a restricted feeding schedule. Eur Neuropsychopharmacol 20: 317-326.

Gelegen C, van den Heuvel J, Collier DA, Campbell IC, Oppelaar H, Hessel E et al (2008). Dopaminergic and brain-derived neurotrophic factor signaling in inbred mice exposed to a restricted feeding schedule. Genes Brain Behav 7: 552-559.

Harrison A, O'Brien N, Lopez C, Treasure J (2010). Sensitivity to reward and punishment in eating disorders. Psychiatry Res 177: $1-11$.

Hebebrand J, Exner C, Hebebrand K, Holtkamp C, Casper RC, Remschmidt $\mathrm{H}$ et al (2003). Hyperactivity in patients with anorexia nervosa and in semistarved rats: evidence for a pivotal role of hypoleptinemia. Physiol Behav 79: 25-37.

Hillebrand JJ, van Elburg AA, Kas MJ, van Engeland H, Adan RA (2005). Olanzapine reduces physical activity in rats exposed to activity-based anorexia: possible implications for treatment of anorexia nervosa? Biol Psychiatry 58: 651-657.

Holmes MM, Mistlberger RE (2000). Food anticipatory activity and photic entrainment in food-restricted $\mathrm{BALB} / \mathrm{c}$ mice. Physiol Behav 68: 655-666. 
Holtkamp K, Konrad K, Kaiser N, Ploenes Y, Heussen N, Grzella I et al (2005). A retrospective study of SSRI treatment in adolescent anorexia nervosa: insufficient evidence for efficacy. J Psychiatr Res 39: 303-310.

Honma K, von Goetz C, Aschoff J (1983). Effects of restricted daily feeding on freerunning circadian rhythms in rats. Physiol Behav 30: $905-913$.

Hou Y, Wu CF, Yang JY, Guo T (2006). Differential effects of haloperidol, clozapine and olanzapine on learning and memory functions in mice. Prog Neuropsychopharmacol Biol Psychiatry 30: 1486-1495.

Jappe LM, Frank GK, Shott ME, Rollin MD, Pryor T, Hagman JO et al (2011). Heightened sensitivity to reward and punishment in anorexia nervosa. Int J Eat Disord 44: 317-324.

Juckel G, Schlagenhauf F, Koslowski M, Filonov D, Wustenberg T, Villringer A et al (2006). Dysfunction of ventral striatal reward prediction in schizophrenic patients treated with typical, not atypical, neuroleptics. Psychopharmacology (Berl) 187: 222-228.

Kaye WH, Frank GK, McConaha C (1999). Altered dopamine activity after recovery from restricting-type anorexia nervosa. Neuropsychopharmacology 21: 503-506.

Kaye WH, Gwirtsman HE, George DT, Ebert MH (1991). Altered serotonin activity in anorexia nervosa after long-term weight restoration. Does elevated cerebrospinal fluid 5-hydroxyindoleacetic acid level correlate with rigid and obsessive behavior? Arch Gen Psychiatry 48: 556-562.

Kaye WH, Gwirtsman HE, George DT, Jimerson DC, Ebert MH (1988). CSF 5-HIAA concentrations in anorexia nervosa: reduced values in underweight subjects normalize after weight gain. Biol Psychiatry 23: 102-105.

Kaye WH, Nagata T, Weltzin TE, Hsu LK, Sokol MS, McConaha C et al (2001). Double-blind placebo-controlled administration of fluoxetine in restricting- and restricting-purging-type anorexia nervosa. Biol Psychiatry 49: 644-652.

Klenotich SJ, Dulawa SC (2012). The activity-based anorexia mouse model. Methods Mol Biol 829: 377-393.

Kron L, Katz JL, Gorzynski G, Weiner H (1978). Hyperactivity in anorexia nervosa: a fundamental clinical feature. Compr Psychiatry 19: 433-440.

Leggero C, Masi G, Brunori E, Calderoni S, Carissimo R, Maestro S et al (2010). Low-dose olanzapine monotherapy in girls with anorexia nervosa, restricting subtype: focus on hyperactivity. J Child Adolesc Psychopharmacol 20: 127-133.

McGurk SR, Lee MA, Jayathilake K, Meltzer HY (2004). Cognitive effects of olanzapine treatment in schizophrenia. Med Gen Med 6: 27.

Meltzer HY, McGurk SR (1999). The effects of clozapine, risperidone, and olanzapine on cognitive function in schizophrenia. Schizophr Bull 25: 233-255.

Mistlberger RE (1994). Circadian food-anticipatory activity: formal models and physiological mechanisms. Neurosci Biobehav Rev 18: $171-195$.

Mondraty N, Birmingham CL, Touyz S, Sundakov V, Chapman L, Beumont $P$ (2005). Randomized controlled trial of olanzapine in the treatment of cognitions in anorexia nervosa. Australas Psychiatry 13: 72-75.

Monteleone P, Maj M (2008). Genetic susceptibility to eating disorders: associated polymorphisms and pharmacogenetic suggestions. Pharmacogenomics 9: 1487-1520.

Mutlu O, Ulak G, Celikyurt IK, Akar FY, Erden F (2011). Effects of olanzapine, sertindole and clozapine on learning and memory in the Morris water maze test in naive and MK-801-treated mice. Pharmacol Biochem Behav 98: 398-404.

Newcomer JW (2007). Metabolic considerations in the use of antipsychotic medications: a review of recent evidence. J Clin Psychiatry 68(Suppl 1): 20-27.

Ozaki N, Goldman D, Kaye WH, Plotnicov K, Greenberg BD, Lappalainen $\mathrm{J}$ et al (2003). Serotonin transporter missense mutation associated with a complex neuropsychiatric phenotype. Mol Psychiatry 8: 933-936.

Pare WP (1975). The influence of food consumption and running activity on the activity-stress ulcer in the rat. Am J Dig Dis 20: 262-273.

Paré WP VG, Isom KE, Reeves JM (1978). Sex differences and incidence of activity-stress ulcers in the rat. Psychol Rep 43: 591-594.

Pare WP, Vincent GP, Natelson BH (1985). Daily feeding schedule and housing on incidence of activity-stress ulcer. Physiol Behav 34: 423-429.

Perry PJ, Lund BC, Sanger T, Beasley C (2001). Olanzapine plasma concentrations and clinical response: acute phase results of the North American Olanzapine Trial. J Clin Psychopharmacol 21 $14-20$.

Petrakis IL, Leslie D, Finney JW, Rosenheck R (2006). Atypical antipsychotic medication and substance use-related outcomes in the treatment of schizophrenia. Am J Addict 15: 44-49.

Pierce WD, Epling WF, Boer DP (1986). Deprivation and satiation: the interrelations between food and wheel running. J Exp Anal Behav 46: 199-210.

Powers PS, Santana CA, Bannon YS (2002). Olanzapine in the treatment of anorexia nervosa: an open label trial. Int J Eat Disord 32: 146-154.

Pramyothin P, Khaodhiar L (2010). Metabolic syndrome with the atypical antipsychotics. Curr Opin Endocrinol Diabetes Obes 17: 460-466.

Ratnovsky Y, Neuman P (2011). The effect of pre-exposure and recovery type on activity-based anorexia in rats. Appetite 56: 567-576.

Rosengarten H, Quartermain D (2002). The effect of chronic treatment with typical and atypical antipsychotics on working memory and jaw movements in three- and eighteen-monthold rats. Prog Neuropsychopharmacol Biol Psychiatry 26: 1047-1054.

Routtenberg A, Kuznesof AW (1967). Self-starvation of rats living in activity wheels on a restricted feeding schedule. J Comp Physiol Psychol 64: 414-421.

Santel S, Baving L, Krauel K, Munte TF, Rotte M (2006). Hunger and satiety in anorexia nervosa: fMRI during cognitive processing of food pictures. Brain Res 1114: 138-148.

Sayers SL, Campbell EC, Kondrich J, Mann SC, Cornish J, O'Brien $\mathrm{C}$ et al (2005). Cocaine abuse in schizophrenic patients treated with olanzapine versus haloperidol. J Nerv Ment Dis 193: $379-386$.

Schlagenhauf F, Juckel G, Koslowski M, Kahnt T, Knutson B, Dembler $\mathrm{T}$ et al (2008). Reward system activation in schizophrenic patients switched from typical neuroleptics to olanzapine. Psychopharmacology (Berl) 196: 673-684.

Skarsfeldt T (1996). Differential effect of antipsychotics on place navigation of rats in the Morris water maze. A comparative study between novel and reference antipsychotics. Psychopharmacology (Berl) 124: 126-133.

Smelson DA, Ziedonis D, Williams J, Losonczy MF, Steinberg ML, Kaune M (2006). The efficacy of olanzapine for decreasing cueelicited craving in individuals with schizophrenia and cocaine dependence: a preliminary report. J Clin Psychopharmacol 26: $9-12$.

Sullivan PF (1995). Mortality in anorexia nervosa. Am J Psychiatry 152: $1073-1074$

Terry Jr AV, Hill WD, Parikh V, Evans DR, Waller JL, Mahadik SP (2002). Differential effects of chronic haloperidol and olanzapine exposure on brain cholinergic markers and spatial learning in rats. Psychopharmacology (Berl) 164: 360-368.

Theisen FM, Haberhausen M, Schulz E, Fleischhaker C, Clement HW, Heinzel-Gutenbrunner M et al (2006). Serum levels of olanzapine and its N-desmethyl and 2-hydroxymethyl metabolites in child and adolescent psychiatric disorders: effects of 
dose, diagnosis, age, sex, smoking, and comedication. Ther Drug Monit 28: 750-759.

Tortorici MA, Kochanek PM, Poloyac SM (2007). Effects of hypothermia on drug disposition, metabolism, and response: a focus of hypothermia-mediated alterations on the cytochrome P450 enzyme system. Crit Care Med 35: 2196-2204.

Verhagen LA, Luijendijk MC, Hillebrand JJ, Adan RA (2009). Dopamine antagonism inhibits anorectic behavior in an animal model for anorexia nervosa. Eur Neuropsychopharmacol 19: 153-160.

Wagner A, Aizenstein H, Mazurkewicz L, Fudge J, Frank GK, Putnam K et al (2008). Altered insula response to taste stimuli in individuals recovered from restricting-type anorexia nervosa. Neuropsychopharmacology 33: 513-523.

Walsh BT, Kaplan AS, Attia E, Olmsted M, Parides M, Carter JC et al (2006). Fluoxetine after weight restoration in anorexia nervosa: a randomized controlled trial. JAMA 295: 2605-2612.

Wang K, Zhang H, Bloss CS, Duvvuri V, Kaye W, Schork NJ et al (2011). A genome-wide association study on common
SNPs and rare CNVs in anorexia nervosa. Mol Psychiatry 16: 949-959.

Watanabe K, Hara C, Ogawa N (1992). Feeding conditions and estrous cycle of female rats under the activity-stress procedure from aspects of anorexia nervosa. Physiol Behav 51: 827-832.

Wolff MC, Leander JD (2003). Comparison of the effects of antipsychotics on a delayed radial maze task in the rat. Psychopharmacology (Berl) 168: 410-416.

Woods DJ, Routtenberg A (1971). "Self-starvation" in activity wheels: developmental and chlorpromazine interactions. J Comp Physiol Psychol 76: 84-93.

Yokoyama F, Onozawa K, Kakui N, Imanishi T (2007). The selective serotonin reuptake inhibitor fluvoxamine suppresses post-feeding hyperactivity induced by food restriction in rats. Pharmacol Biochem Behav 87: 98-103.

Zhang XY, Zhou DF, Cao LY, Wu GY, Shen YC (2005). Cortisol and cytokines in chronic and treatment-resistant patients with schizophrenia: association with psychopathology and response to antipsychotics. Neuropsychopharmacology 30: 1532-1538.

Supplementary Information accompanies the paper on the Neuropsychopharmacology website (http://www.nature.com/npp) 